\title{
A comparison of two techniques to discriminate continental origin of Atlantic salmon (Salmo salar L.) off West Greenland
}

\author{
David Reddin ${ }^{(1)}$, Hélène de Pontual ${ }^{(2)}$ and Patrick Prouzet ${ }^{(3)}$ \\ (1) Science Branch, Department of lïsheries and Oceans, \\ PO Box 5607 , Sl. John's, Newfoundland $\mathrm{A}_{I} \mathrm{C}_{5} \mathrm{X}_{I}$, Canada. \\ (2) Institut Français de Recherche pour l'Exploitation de la Mer, Centre de Brest, \\ DRVIPA, BP'337, 29273 Brest Cedex, France. \\ (3) Institut Français de Recherche pour l'Exploitation de la Mer, \\ Station d'Iydrobiologie INRA, BP 3 , \\ $6_{4310}$ Sainl-Pée-sur-Nivelle, France.
}

Reccived June I 7, I991; accepted February I4, I $99^{2}$.

Reddin D., H. de Pontual, P. Prouzet. Aquat. Living Resour., 1992, 5, 81-88.

Abstract

Two tcchniques of stock discrimination both utilizing scales, i.e. termed as classical technique and shape analysis, are compared for discriminating between North American and Europcan Atlantic salmon (Salmo salar L.) caught off West Greenland. Three scales from each of 60 salmon were analyzed: 30 from North American and 30 from European-origin salmon collected from home rivers in 1982. The best results indicated misclassification and error rates of $0 \%$ for shape analysis and $5.0 \%$ and $\pm 1.7 \%$, respectively, for the classical technique. A nested ANOVA indicated that variation was greater between scales of salmon of North American and European origin than from several scales from the same salmon. It was concluded that shape analysis with computer-aided devices may be superior to the classical technique and it is recommended that it be examined for use at West Greenland.

Keywords : Salmo salar, meristics, shape analysis, discrimination.

Comparaison de deux techniques pour déterminer le continent d'origine des saumons atlantiques (Salmo salar L.) capturés dans l'ouest du Groenland.

Résumé

Les résultats obtenus par deux techniques de discrimination pour séparer les captures de saumons issues des continents Nord américain et européen, à partir des écailles (caractéristiques de la structure interne ou analyse de sa forme) sont comparés. Sur chacun des 60 saumons étudiés (30 pour chaque continent), 3 écailles sont analysćes. Les échantillons de base ont été récoltés en 1982 dans les rivières d'origine. Les meilleurs résultats donnent des taux d'erreur et de mauvais classement de $0 \%$ pour l'analyse de la forme et de 5 et 1,7\% pour la technique classique. L'analyse de variance indique que la variation entre écailles de saumons de continents différents est supérieure à celle observée à partir de plusieurs écailles d'un même saumon. En définitive, les auteurs concluent à la meilleure efficacité de l'analyse de forme de l'écaille pour la sćparation des stocks de saumons et ils recommandent que son utilisation soit envisagée pour la pêcherie ouest-groenlandaise.

Mots-clés : Salmo salar, scalimétric, analyse de forme, discrimination. 


\section{INTRODUCTION}

Atlantic salmon (Salmo salar L.) are distributed at sea over much of the northern half of the Atlantic Ocean (Anon., 1984a) and are exploited at several locations where stocks are concentrated on feeding grounds and along migration roules, e. g. West Greenland, Faroes, Newfoundland, etc. (Saunders, 1981). The very nature of exploitation of salmon in mixedstock fisheries causes several problems for managers, one of the more important of which may be the overexploitation of less productive stocks if exploitation rates are high (Ricker, 1975; Anon., 1982 and 1988). Consequently, scientific investigations to assess the effects of these fisheries on homewater stocks and fisheries have focused attention on estimating the proportions of the component stocks. For example, the salmon catch at Greenland consists almost exclusively of salmon that originated in rivers of Europe and North America (Anon., 1979). Many techniques were investigated for their potential in separating these two components, including tagging of adults and smolts, protein electrophoresis, parasites, and discriminant analysis of scalc characters (Parrish and Horsted, 1980).

Since 1969 , a technique based upon the discriminant analysis of scale characters has been used to separate the two continental components of the catch in the Greenland fishery. This approach, referred to in this paper as the classical technique, was initially developed for use in the Greenland fishery by Lear and Sandeman (1980) and subsequently modified by Reddin (1986). Each of these analyses was based on meristic scale characters to differentiate the two groups. De Pontual and Prouzet (1987 and 1988) noted that these methods may be sensitive to the scale reader's ability to locate the zones on the scales used in the analyses (Reddin et al., 1988). As demonstrated by de Pontual and Prouzet (1987 and 1988), scale-shape analysis can sometimes be an effective tool for stock discrimination that may have several advantages over classical techniques. For example, scale-shape analysis readily lends itself to automation with compuler-controlled devices, thereby eliminating any bias from reader interpretation. Also, the variables generated by scaleshape analysis contain properties of the entire scale and thus may be a better tool to differentiate between stocks. However, the relative discriminating power of the two techniques has never been directly compared.

In this paper, two techniques of stock differentiation, scale-shape analysis (de Pontual and Prouzet, 1987 and 1988) and the classical technique using meristic scale characters (Reddin, 1986), are applied to the same scales and their ability to discriminate between North American and European salmon on the same data set are directly compared.

\section{METHODS}

In this paper, we are comparing the efficacy of two techniques of capturing information from scales, viz. classical and shape, for discriminating between North American and European salmon. In order to ensure that the results from these techniques are directly comparable, the analyses and scale material for discrimination must be as similar as possible. Consequently, the same scales and statistical treatments were used for both techniques and the results of the analyses were directly compared.

\section{Scale samples for analysis}

Scales are a logical choice for separating stocks in mixed-stock fisheries, since they have been used previously to differentiate stocks of salmon caught on the high seas to continent of origin for both Pacific and Atlantic salmonids (Lear and Sandeman, 1980; Major et al., 1975). Scales were chosen over other body parts, as they are inexpensive to obtain, casy to collect and frequently available. Also, scales easily lend themselves to shape analysis and circuli counting.

Scale samples for this analysis were selected randomly from samples assembled by Reddin et al. (1984) to discriminate between salmon of North American and European origin. Before selection, the material consisted of scale samples from 2-sea-winter ( $2 \mathrm{SW}$ ) salmon sampled in homewaters in 1982 of known North American $(\mathrm{N}=150)$ and European $(N=196)$ origin. Thirty salmon from each of the North American and European groups were chosen at random from those available. So that the two methods could be compared for within-fish variability, three scales from each fish were selected for analysis. The scales were taken from the standard area, i.e. on the left side of the fish and from three to six rows above the lateral line and on a line extending from the anterior edge of the anal fin to the posterior edge of the dorsal fin (Anon., 1984b). Scales were mounted between two glass slides after cleaning with sodium peroxide. Annuli were discerned for ageing by standard criteria (Anon., 1984 b).

\section{Scale morphology and meristic variables}

An image analysis system, details of which are given in de Pontual (1986), de Pontual and Prouzet (1987 and 1988), was used to extract the quantitative information from scales. Schematically, we describe the image analysis microsystem as follows. 
Image processing: a charge coupled device (CCD) provides a digital signal $(208 \times 144$ pixels $)$ and a brightness resolution of 64 Grey levels. From the digitization of the image (conversion of an analog image into a discrete digital form that can be used by a computer), we partitioned the image into two significant regions: scale and background by the segmentation process (choice of a threshold level of brightness). This resulted in a bilevel image in which the scale appeared as a black silhouette on a white background. From this bilevel picture, we easily extracted the contour of the scale. This contour was finally represented by chain codes according to Freeman's method (1961 and 1964).

Feature extraction: from the chain-coded contour of the scales, three types of shape descriptors were computed:

(i) simple shape factors:

$\mathrm{F} 1=$ perimeter/square root of the area;

$\mathrm{F} 2=$ perimeter/length;

F 3 = perimeter/width;

$\mathrm{F} 4=$ square root of the area/length;

$\mathrm{F} 5=$ square root of the area/width;

$\mathrm{F} 6=$ width/length;

F $7=$ area/area of the minimum circumscribed rectangle;

(ii) moment invariants: seven moment invariants were extracted. Moment invariants have been used in a number of studies dealing with biological shapes (Butler et al., 1964; Berman et al., 1984; and Jeffries et al., 1984);

(iii) elliptic Fourier coefficients: the contour of the scale was characterized by a series of components called harmonics whose coefficients can be used as shape descriptors. The coarse shape was determined by harmonics of low frequency and the addition of successively higher order harmonics increases the accuracy of shape description. The method used here to extract the Fourier coefficients from the chaincoded contours was that of Kuhl and Giardina (1982).

After extraction of the three types of shape descriptors, the data consisted of 180 sets of scale-shape variables, including 3 from each salmon. For each scale, variables for analysis included 7 shape factors (F 1-F 7), 7 moment invariants (M 1-M 7), and Fourier coefficients from 20 harmonics (A 2-A 20 and B 1B 20), i.e. 53 variables in total. All variables used were standardized for size as described in de Pontual and Prouzet (1987 and 1988).

For the classical technique of circuli counts, full details on the method of circuli counting are given in Reddin (1986) and Reddin et al. (1988). The variables used were circuli counts in the zone of widest circuli spacings (CS $1 \mathrm{~S}(45)$ ) and narrowest (CS $1 \mathrm{~W}(45)$ ), read at $45^{\circ}$ from the longitudinal axis of the scale. The same three scales from each fish were interpreted as for the scale-shape analysis.

\section{Statistical analysis and variable selection}

Our aim was to determine whether morphological scalc-shape descriptors are a better tool than the classical technique currently in use for classifying salmon caught off West Greenland into their continent of origin. The objective of classifying salmon into their continent of origin suggested the appropriateness of a multivariate approach which recognizes the interdependence of variables and provides a single composite of these, determined in some optimal way. The technique most commonly used for this is discriminant analysis, similarly used by others for problems of this type (Lear and Sandeman, 1980; Cook, 1982; Reddin, 1986). Computer programs used were Statistical Analysis Systems-DISCRIM, STEP, MEANS, and GLM procedures (Statistical Analysis Systems, 1985). Since there are too many parameters for the number of available data points (Bliss, 1980), the best variables were selected on the basis of the highest F-score from analysis of variance (ANOVA). A nested ANOVA design was chosen to test the null hypotheses that there are no differences among the means of shape descriptors and meristic coefficients between continents, and that all of the sampling variation is from variation within scales (Dunn and Clark, 1974). The second hypothesis will allow us to assess whether the variation is greater between fish or between scales. Further variable selection was done by a step-by-step (STEPWISE) discriminant analysis procedure, choosing variables to enter or leave the model on the basis of the significance level of an Ftest by ANOVA. The significance level for entering or leaving was $P=0.05$. A number of stepwise discriminant analyses were done, including separate analyses for shape factors, moment invariants, Fourier coefficients, and all variables combined. The best combinations of variables from this procedure were then input into the discriminant analysis. The means of the selected variables calculated from three scales per fish were input into the discriminant analysis.

The discriminant model used for classification in this paper was based on a measure of generalizedsquared distance (Rao, 1973), employing either the individual within-group covariance matrices or the pooled covariance matrix. To account for within-fish variability, the discriminant analysis used the mean vector of the three vectors available per fish, reducing the data matrix to 60 mean vectors, one for each fish. For each discriminant analysis, Kendall and Stuart's chi-square was used to test for homogeneity of the within-group covariance matrices of the European and North American groups (Kendall and Stuart, 1961). If this test was significant, then a quadratic model was used for discrimination (Cook, 1982) and, if not, then the appropriate linear model was used (Reddin, 1986). All of the discriminant analyses, similar to the stepwise discriminant analysis, used the means of the selected variables calculated from three scales per fish. The prior probabilities were equal, i.e. 
prior to observing the selected scale variables on a given fish, the probability of North American origin equals the probability of European origin, 0.5.

The results of the two techniques were assessed by comparing their error and misclassification rates. The misclassification rate was assessed by classifying the same 60 fish used to form the discriminant analysis database and summing the number of misclassed fish (Reddin et al., 1988). Error rate was calculated as the difference between the actual proportion of North American and European salmon and the proportion calculated from the classification procedure on a sample of known origin (Reddin et al., 1988). The best technique was deemed to be the one with the lowest misclassification and error rates.

\section{RESULTS}

The null hypothesis, viz $F 1$ in table 1 , that there were no differences among the means of the scaleshape variables between continents was rejected for 16 characters out of 53 at less than the $5 \%$ level of significance (table 1). Therefore, differences between some of the mean scale-shape descriptors for North American and European salmon were significant, indicating a difference in scale morphology between North $A$ merican and European salmon. These are the best variables for discriminating between North Amcrican and European salmon. For the classical technique, the differences between means of North American and European salmon for both variables were also significant at the $5 \%$ level (table 1$)$. This suggests that both of the classic variables and several of the scale-shape descriptors will have some efficacy in discriminating between North American and European salmon.

The other null hypothesis, viz. F 2 in table 1, tested whether the sampling variation for scale characters within continent was greater between fish (do not reject the null hypothesis) or between scales (accept the null hypothesis). For scalc-shape variables, there were 24 cases out of 53 where the null hypothesis was rejected at the $5 \%$ level of significance, indicating that, for these scale-shape descriptors, variation was greater from fish to fish than from scale to scale within a fish. The best variables for discrimination between North American and European salmon will be those scale-shape descriptors that were significant for both F 1 and F 2 tests. For the classical technique, $\mathrm{F} 2$ for both variables was significant at the $5 \%$ level of significance. This indicates that, for these variables, variation was greater from fish to fish than from scale to scale within a fish.

Results of discriminant analysis of scale characters from the classical technique indicated a misclassification rate of $5.0 \%$ and error rate of $\pm 1.7 \%$ (table 2 ). This is quite acceptable and is comparable to the rates reported by Reddin et al. (1988), from which the scales for this paper were chosen. Reddin et al. (1988) reported misclassification rates of $6.6 \%$ and crror rates of $\pm 0.4 \%$, but calculated on the entire data set.

Results of discriminant analysis for scale-shape indicated that a number of variables were useful for discriminating between North American and European salmon (table 3). Performance of the various combinations was assessed using the misclassification and error rates and showed that, of the three types, the Fourier coefficients were more useful than either the shape factors or moment invariants. In spite of this, the three types were still used together in the discriminant analysis to discern the best discriminating dataset. The misclassification rate for the Fourier coefficients was $8.3 \%$, compared to $23.3 \%$ for moment invariants and $26.7 \%$ for the shape factors. Similarly, error rates for Fourier coefficients were $\pm 3.0 \%$ and $\pm 16.7 \%$ for moment invariants and $\pm 13.0 \%$ for shape factors. Various combinations of selected subsets of all variables showed misclassification rates ranging from 0 to $8.3 \%$ and error rates of $0 \%$ (most frequent) to $\pm 5.0 \%$ (table 3 ).

The most powerful subset of variables will be the one with misclassification and error rates closest to or equal to zero. Thus, for the shape analysis, trial number 8 was the best and is used to compare to the classical technique. Trial 8 used a subset of characters from all three shape features, i.e. shape factors, moment invariants, and Fourier coefficients (table 3). The results indicate that both misclassification and crror rates were $0.0 \%$ (table 4 ). This is much better than could be obtained with the classical technique where misclassification and error rates were 5.0 and $\pm 1.7 \%$, respectively (table 2 ). Trials 6 and 7 from shape analysis were also superior to the classical techniques as misclassification rates were 6.7 and $3.3 \%$, respectively, with error rates of $\pm 0.0 \%$ in both cases. Thus, several discriminant models could be formed from the scale-shape descriptors that gave superior results to those obtained from the classical techniques.

\section{DISCUSSION}

Most of the marine fisheries for Atlantic salmon harvest fish when they are mixed on fecding grounds or as they return to their home rivers to spawn (Saunders, 1981). This is definitely the case off West Greenland where Atlantic salmon from Canadian, USA, Scottish, English, Irish, French, Spanish, and other rivers (Moller Jensen, $1980 a$ and $1980 b$ ) are harvested by the fishery. The mixed nature of the stocks off Greenland has made stock assessment using common techniques difficult (Ricker, 1971) and, consequently, Ritter et al. (1980) used an empirical model to assess the effects of this fishery on homewater stocks and fisheries. Since it was relatively easy to separate the catch into its two major components-European and 
Tatike 1. - Results of hypothesis tests to compare classical and scale-shape analysis for discriminating between North American and

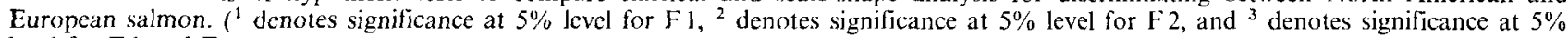
level for F I and F 2).

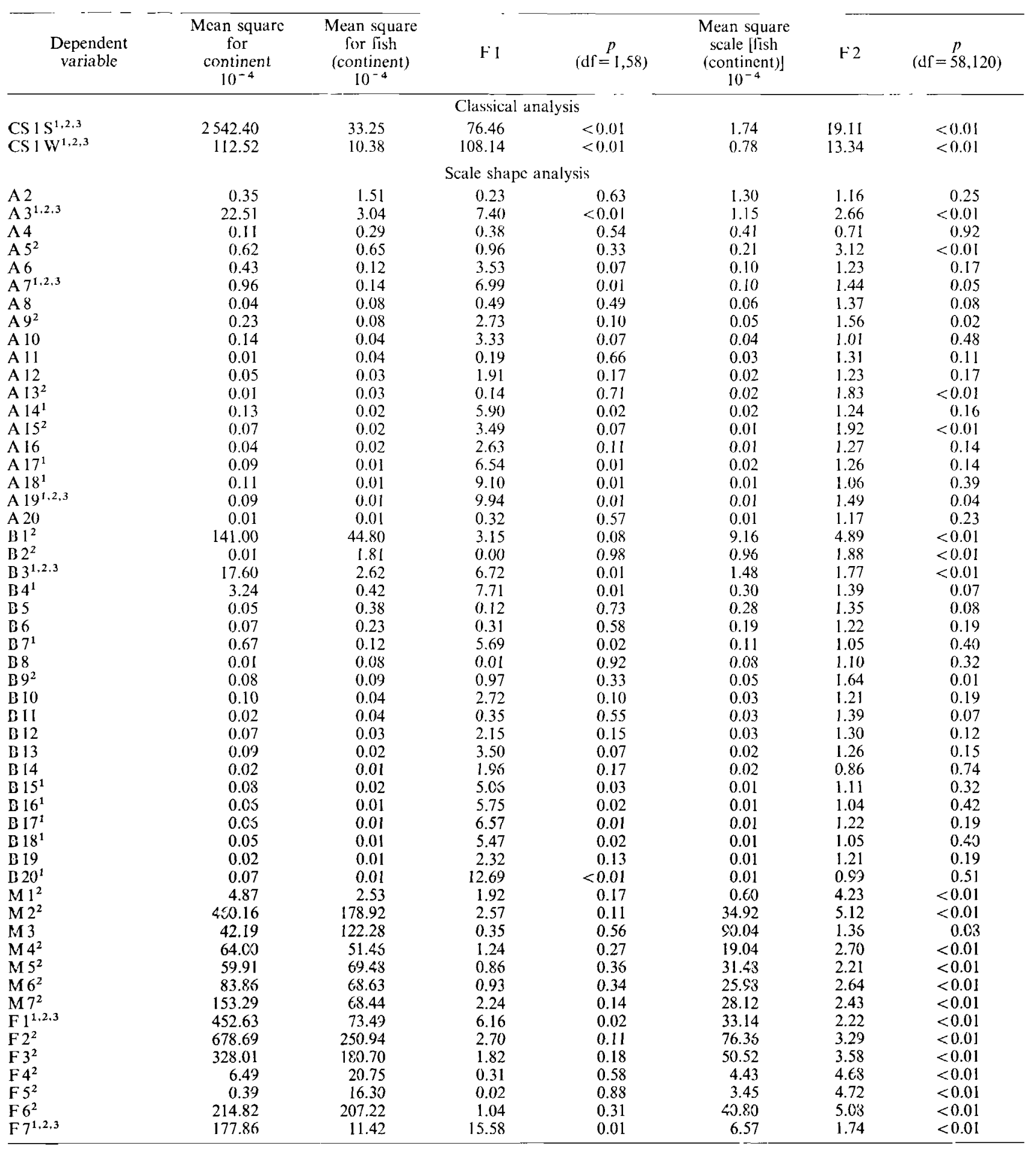

North American salmon-by discriminant analysis (Lear and Sandeman, 1980), Ritter's model began with the catch at Greenland divided into numbers of North American and European origin salmon.
The classical technique of Lear and Sandeman (1980), and more recently Reddin (1986), employed discriminant analysis of scale characters to separate North American from European salmon. In both

Vol. $5, n^{\circ} 2-1932$ 
Table 2. - The results of classification using variables CS 1 W (45) and CS $1 \mathrm{~S}$ (45) from classical technique for samples collected in Europe and North America in 1982.

\begin{tabular}{|c|c|c|c|}
\hline \multirow{2}{*}{ Actual group } & \multicolumn{2}{|c|}{$\begin{array}{l}\text { Predicted group } \\
\text { member ship }\end{array}$} & \multirow{2}{*}{ Total } \\
\hline & $\begin{array}{c}\text { North } \\
\text { America }\end{array}$ & Europe & \\
\hline North America & $\begin{array}{l}28 \\
93.3 \%\end{array}$ & $\begin{array}{l}2 \\
6.7 \%\end{array}$ & 30 \\
\hline Europe & $\begin{array}{l}1 \\
3.3\end{array}$ & $\begin{array}{l}29 \\
96.7\end{array}$ & 30 \\
\hline Total & $\begin{array}{l}29 \\
48.3 \%\end{array}$ & $\begin{array}{l}31 \\
51.7 \%\end{array}$ & 60 \\
\hline $\begin{array}{l}\text { Actual percentage } \\
\text { Priors }\end{array}$ & $\begin{array}{l}50.0 \% \\
0.5000\end{array}$ & $\begin{array}{l}50.0 \% \\
0.5000\end{array}$ & \\
\hline
\end{tabular}

Percentage of "grouped" individuals incorrectly classilied: $5.0 \%$. Error rates: $\pm 1.7 \%$.
Table 4. - The results of classification using variables from scale shape analysis for samples collected in Europe and North $A$ merica in 1982. The quadratic discriminant model was used.

\begin{tabular}{lccc} 
& \multicolumn{2}{c}{$\begin{array}{c}\text { Predicted group } \\
\text { membership }\end{array}$} \\
Actual group & $\cdots$ & & \\
& North & Furope & \\
& America & & \\
North America & $-\overline{0}$ & 0 & 30 \\
& $100.0 \%$ & $0.0 \%$ & \\
Europe & 0 & $30 \%$ & 30 \\
Total & 0.0 & 100.0 & \\
& 30 & $30 \%$ & 60 \\
True perccntage & $50.0 \%$ & $50.0 \%$ & \\
Prior probabilities & $50.0 \%$ & $50.0 \%$ & \\
\hline
\end{tabular}

Percentage of "grouped" individuals incorrectly classified: $0.0 \%$. Frror rates (true - predicted percentages): $\pm 0.0 \%$.

Table 3. - Accuracy of different subsets of features to discriminate between North American (NA) and European (E) salmon using shape analysis (Q: quadratic model, L: linear model).

\begin{tabular}{|c|c|c|c|c|c|c|c|c|}
\hline \multirow{2}{*}{$\begin{array}{l}\text { Trial } \\
\text { no. }\end{array}$} & \multirow{2}{*}{$\begin{array}{l}\text { Original } \\
\text { features }\end{array}$} & \multirow[t]{2}{*}{ Model } & \multirow{2}{*}{$\begin{array}{l}\text { Selected } \\
\text { variables }\end{array}$} & \multirow{2}{*}{$\begin{array}{l}\text { Actual } \\
\text { proportion } \\
\text { NA \& E }\end{array}$} & \multicolumn{2}{|c|}{$\begin{array}{l}\text { Classified } \\
\text { proportion }\end{array}$} & \multirow{2}{*}{$\begin{array}{c}\text { Misclassed } \\
\%\end{array}$} & \multirow{2}{*}{$\begin{array}{c}\text { Bias } \\
\%\end{array}$} \\
\hline & & & & & NA & E & & \\
\hline 1 & Shape factors & Q & F 7 & 0.5 & 0.63 & 0.37 & 26.7 & \pm 13.3 \\
\hline 2 & $\begin{array}{c}\text { Moment } \\
\text { invariants }\end{array}$ & $Q$ & $\begin{array}{c}\text { M } 1 \text { M M } 3 \text { M } 4 \text { M } \\
\text { M } 6 \text { M } 7\end{array}$ & 0.5 & 0.67 & 0.33 & 23.3 & +16.7 \\
\hline 3 & $\begin{array}{l}\text { Fourier } \\
\text { coefficients }\end{array}$ & Q & $\begin{array}{l}\text { B } 20 \text { A } 7 \text { B } 3 \text { B } 4 \\
\text { A } 13 \text { A } 5 \text { B } 18 \text { B } 9\end{array}$ & 0.5 & 0.53 & 0.47 & 8.3 & \pm 3.0 \\
\hline 4 & All variables & $Q$ & $\begin{array}{c}\text { A } 13 \wedge 17 \text { B } 4 \text { B } 17 \\
F 7\end{array}$ & 0.5 & 0.55 & 0.45 & 8.3 & \pm 5.0 \\
\hline 5 & All variables & $Q$ & $\begin{array}{c}\text { B } 20 \text { A } 7 \text { B } 3 \text { B } 4 \text { A } 13 \\
\text { F } 7 \text { A } 5 \text { B } 18 \text { B } 9\end{array}$ & 0.5 & 0.53 & 0.47 & 6.7 & \pm 3.3 \\
\hline 6 & All variables & $\mathrm{L}$ & $\begin{array}{c}\text { F } 7 \text { A } 13 \text { A } 17 \text { B } 4 \text { B } 17 \\
\text { M } 4 \text { A } 7\end{array}$ & 0.5 & 0.50 & 0.50 & 6.7 & $\pm \quad 0.0$ \\
\hline 7 & All variables & Q & $\begin{array}{c}\text { F7 } 113 \text { A } 17 \text { B } 4 \text { B } 17 \\
\text { M } 4 \text { A } 7 \text { A } 6\end{array}$ & 0.5 & 0.50 & 0.50 & 3.3 & \pm 0.0 \\
\hline 8 & All variables & $Q$ & $\begin{array}{c}\text { F } 7 \text { A } 13 \text { A } 17 \text { B } 4 \text { B } 17 \\
\text { M A } 7 \text { A } 6 \text { A B } 18 \text { A } 11\end{array}$ & 0.5 & 0.50 & 0.50 & 0.0 & \pm 0.0 \\
\hline
\end{tabular}

cases, circuli counts of various river and sea zones or parts thereof were used as discriminators. It should be noted that discriminant analysis of scale characters has proved to be more efficacious than biochemical methods. However, the types of variables used in these classical techniques require that the scale reader decide the beginning and end of the character to be interpreted, and then which circuli to include or exclude. While the results of these counts were shown to be repeatable with low variability (Reddin et al., 1984), a less subjective technique would be scientifically more desirable. The analysis of scale morphology, because it has been automated by linking digitizers with micro-computers (Freeman, 1974; Kuhl and Gardinia, 1982; de Pontual and Prouzet, 1987 and 1988), was known to be less subjective than the current method. Since analyses of scale morphology have been applied to walleye successfully (Jarvis et al., 1978), and previously to Atlantic salmon (de Pontual et al., 1983), it was thought it might be a useful tool for separating stocks of salmon caught off West Greenland.

In the current situation, discriminant analysis of scale-shape descriptors gave a low number of misclassifications with little error in the proportions. The record for the classical technique, while acceptable for discrimination, was not as good. Both misclassification and error rates were higher for the classical technique than for the scale-shape method. Other classical techniques, using discriminant analysis to scparate North American from European salmon, have shown a misclassification rate of $15 \%$ and error rate of $\pm 7 \%$ in favour of North American salmon (Lear and Sandeman, 1980). Reddin (1986) updated 
the analysis of Lear and Sandeman and showed a misclassification rate of only $2 \%$, with a $\pm 2 \%$ error in Favour of European salmon. Subsequent analyses by Reddin et al. (1988) have shown misclassification rates of 4.6 to $6.6 \%$ and error rates from \pm 0.4 to $\pm 0.9 \%$. Therefore, discriminant analysis of shape descriptors seems to perform consistently better than that of classical technique.

Shape analysis has several further advantages over classical techniques. Since the shape variables are generated using standard procedures with computcrassisted devices, they are more easily reproducible. Reddin (1987) and Reddin et al. (1988) demonstrated that, while scale characters used by classical techniques can be reproduced, there is error associated with them. This error arises from both within- and between-reader variability in counting or measuring circuli. Therefore, an added advantage of shape analysis over the classical techniques is the avoidance of error due to reader interpretation. There may also be other advantages, i.e. speed of analysis, in changing to this technique. Some further improvements in discriminating power may be possible by adding information from the internal scale structure, $i$.e. intercirculi spacings, as proposed by Troadec and Prouzet (1986).

However, before adopting shape analysis for identifying North American and European salmon off Greenland, several factors should be considered.

- Shape coefficients have been shown to vary due to sex and age by de Pontual et al. (1983). This may require that the contour used to describe the shape coefficients come from the same location on the scale of salmon sampled from the catch off West Greenland when the fish are $1 \mathrm{SW}$ in age as for those salmon used in the database of known origin when they are $2 \mathrm{SW}$ in age.

- Annual variation in scale morphology needs to be examined to learn how stable they are over time.

- In order to ensure that the scale database comes from wild salmon, fish farm escapees will have to be eliminated from the database. Escapees from fish farms have been observed mixed together in catches of salmon in Norway and Scotland (Anon., 1990).

- This analysis was exploratory in nature and therefore we were justified in using a smaller dataset. If the technique used to identify salmon off West Greenland is changed to scale-shape, then a larger sample of known-origin salmon from more countries/ rivers in Europe and North American will be required for the database.

In summary, we have shown scale shape may perform better than the classical technique of circuli counting and we recommend that it be further investigated.

\section{REFERENCES}

Anonymous, 1979. Report of the Working Group on North Atlantic Salmon. Cons. Int. Explor. Mer C.M. 1979/M:10, 50 p.

Anonymous, 1982. Report of Meeting of the Working Group on North Atlantic Salmon. Cons. Int. Explor. Mer C.M. 1982/Assess: 19, 51 p.

Anonymous, 1984a. Report of Mecting of the Working Group on North Atlantic Salmon. Cons. Int. Explor. Mer. C.M. 1984/Assess: 16, 58 p.

Anonymous, $1984 \mathrm{~b}$. Atlantic salmon scalc reading. Report of the Atlantic Salmon Scale Reading Workshop. Cons. Int. Explor. Mer C.M. 1984, 17 p.

Anonymous, 1988. Report of the Working Group on North Atlantic Salmon. Cons. Int. Explor. Mer C.M. 1988/ Assess: 16, $112 \mathrm{p}$.

Anonymous, 1990. Report of the Working Group on North Atlantic Salmon. Cons. Int. Explor. Mer C.M. 1990/ Assess: $11,133 \mathrm{p}$.

Bliss C. I., 1970. Statistics in biology. Vol. 2. McGraw-Hill Book Co., 639 p.

Berman M. S., J. R. Green, K. Sherman, 1984. Application of image analysis to the marine ecosystem studics. ICES C.M. 1984/L:8.

Butler J. W., M. K. Butler, A. Stroud, 1964. Automatic classilication of chromosomes. In: Data acquisition and processing in biology and medicine. K. Enslein Ed., Pergamon Press.

Cook R. C., 1982. Stock identification of sockeye salmon (Oncorhynchus nerka) with a scalc pattern recognition. Can. J. Fish. Aquat. Sci., 39, 611-617.

Dunn O. J., V. A. Clark, 1974. Applied statistics: analysis of variance and regression. J. Wilcy and Sons, New York.

Freeman H., 1974. Computer processing of line drawing images. Comput. Surv., 6, 57-97.

Freeman H., 1961. On the encoding of arbitrary geometric configurations. IRE transactions on computers, EC 10, 421-432.

Jarvis R. S., H. F. Klodowski, S. P. Sheldon, 1978. New method of quantifying scalc shape and an application to stock identification in Wailcye (Stizostedion vitreum vitreum). Trans. Am. Fish. Soc., 107, 528-534.

Jeffries H. P., M. S. Berman, A. D. Poularikas, C. Katsinis, I. Melas, K. Sherman, L. Bivins, 1984. Automated sizing, recognition. Mar. Biol., 78, 329-334.

Kendall M. G., A. Stuart, 1961. The advance theory of statistics. 3, Charles Griffin and Co. Ltd., London.

Kuhl F. P., C. R. Giardina, 1982. Elliptic Fourier features of a closed contour. Computer graphics and image processing, 18, 236-258.

Lear W. H., E. J. Sandeman, 1980. Use of scale characters and discriminant functions for identifying continental origin of Atlantic salmon, 68-75. In: ICES/ICNAF Joint Investigation on North Atlantic Salmon. Rapp. P.-v. Réun. Cons. int. Explor. Mer, 176.

Major R. L., A. Murai, J. Lyons, 1975. Scale Studies to identify Asian and western Alaskan chinook salmon. Int. North Pac. Fish. Comm. Annu. Rep. 1973, 80-91. 
M $\not l l e r$ Jensen J., 1980. Recaptures of salmon at West Greenland tagged as smolts outside Greenland waters, 114-121. In ICES/ICNAF Joint Investigation on North Atlantic Salmon. Rapp. P.-v. Réun. Cons. int. Explor. Mer, 176.

Møller Jensen J., 1980. Recaptures from international tagging experiments at West Greenland, 122-135. In ICES ICNAF Joint Investigation on North Atlantic Salmon. Rapp. P.-z. Réun. Cons. int. Explor. Mer, 176.

Parrish B. B., Sv. Aa. Horsted (cd), 1980. ICES/ICNAF Joint Investigation on North Atlantic Salmon. Rapp. P.-v. Réun. Cons. int. Explor. Mer, 176, 146 p.

Pontual H. de, C. Liacopoulos, P. Prouzet, 1983. Essai de différentiation de deux stocks de saumon Atlantique (Salmo salar L.) par reconnaissance de la forme de leurs écailles. Cont. Int. Explor. Mer C.M. 1983/M:18, 8 p.

Pontual H. de, 1986. Essais de discrimination des stocks de saumons atlantiques (Salmo salar L.) par reconnaissance de la forme de leurs écailles. Thèse Doctorat Univ. Paris-VI, spécialité Biologic, 167 p.

Pontual H. de, P. Prouzet, 1987. Atlantic salmon, Salmo salar L., stock discrimination by scale-shape analysis. Aquacult. Fish. Manage., 12, 277-289.

Pontual H. de, P. Prouzet, 1988. Numerical analysis of scale morphology to discriminate between Atlantic salmon stocks. Aquat. Living Resour., 1, 17-27.
Rao C. R., 1973. Linear statistical inference and its applications. John Wilcy and Sons, New York, $522 \mathrm{p}$.

Reddin D. G., 1986. Discrimination between Atlantic salmon (Salmo salar L.) of North American and European origin. J. Cons. int. Explor. Mer, 43, 50-58.

Reddin D. G., R. F. Burfitt, P. B. Short, 1984. Identification of North American and European Atlantic salmon (Salmo sular L.) caught off West Greenland in 1982-83. Cons. int. Explor. Mer C.M. 1984/M:12, 18 p.

Reddin D. G., D. E. Stansbury, P. B. Short, 1988. Continent of origin of Atlantic salmon (Salmo salar L.) at West Greenland. J. Cons, int. Explor. Mer, 44, 180-188.

Ricker W. E., 1975. Computation and interpretation of biological statistics of fish populations. Bull. Fish. Res. Board Can., 191, 382 p.

Ritter J. A., T. L. Marshall, D. G. Reddin, W. G. Doubleday, 1980. Assessment of the impact of the West Greenland lishery on stocks and catches in North America. Cons. Int. Explor. Mer C.M. 1980/M : 38, 10 p.

Saunders R. L., 1981. Allantic salmon (Salmo salar) stocks and management implications in the Canadian Atlantic provinces and New England, U.S.A. Can. J. Fish. Aquat. Sci., 30, 1612-1625.

Statistical Analysis Systems, 1985. SAS user's guide: statistics. SAS Institute Inc., Cary, North Carolina, $584 \mathrm{p}$.

Troadec H., P. Prouzet, 1986. An attempt of age and growth determination of Atlantic salmon (Salmo salar L.) using image analysis of their scales. ICE.S, C.M. $1986 / \mathrm{M}: 14$ 